\title{
Growth of Nile tilapia post-larvae from broodstock fed diet with different levels of digestible protein and digestible energy ${ }^{1}$
}

\section{Silia Maria de Negreiros Sousa², André Freccia², Lilian Dena dos Santos³, Fábio Meurer², Lucélia Tessaro ${ }^{4}$, Robie Allan Bombardelli ${ }^{5}$}

\footnotetext{
${ }^{1}$ Research supported by Fundação Araucária de Apoio ao Desenvolvimento Científico e Tecnológico do Paraná.

${ }^{2}$ Graduate Program in Animal Science - Unioeste, Campus Marechal Cândido Rondon, PR, Brazil. CAPES-supported graduate student.

${ }^{3}$ Course of Aquaculture Technology - UFPR, Campus Palotina, PR, Brazil.

${ }^{4}$ Graduate Program in Aquaculture - CAUNESP, Campus Jaboticabal, SP, Brazil.

${ }^{5}$ Graduate Program in Animal Science - Unioeste, Campus Marechal Cândido Rondon, and Graduate Program in Fishery Resources and Fishery Engineering - Unioeste, Campus Toledo, PR, Brazil.
}

\begin{abstract}
This study was carried out to evaluate the influence of different levels of digestible energy and digestible protein in diets of Nile tilapia (Oreochromis niloticus) broodstock on offspring growth during sex reversal stage. A total of 2,700 post-larvae $(8.2 \pm 0.001 \mathrm{mg})$ derived from breeders fed nine diets with distinct levels of digestible protein $(28,34$ and $40 \%$ DP) and digestible energy $\left(2,800 ; 3,400\right.$; and 4,000 kcal DE. $\left.\mathrm{kg}^{-1}\right)$ were stored in twenty-seven $70 \mathrm{~L}$ tanks. After 30 days of growth, their average final weight (AFW, g), average weight gain (AWG, g), final standard length (SL, cm), condition factor (CF), specific growth rate (SGR, \%/day), stock uniformity (UNI, \%), survival (SUR, \%) and sex reversal rate (SRR, \%) were measured. Although female nutrition is thought to influence the performance or quality of progeny during early life stages, no influence of diets supplied to broodstock was detected on any parameter. Nonetheless, the offspring presented commercially satisfactory growth rates. Thus, diets containing $28 \%$ of digestible protein and 2,800 kcal of digestible energy.kg of diet ${ }^{-1}$ can be used to feed Nile tilapia broodstock without jeopardizing offspring performance during the sex reversal phase.
\end{abstract}

Key Words: fry, nutrition, Oreochromis niloticus, reproduction, sex reversal

\section{Introduction}

The Nile tilapia production outside its native range (El-Sayed et al., 2005) represents about $8 \%$ of the total of freshwater fish produced worldwide (FAO, 2010). In this scenario, the Brazilian fishery production increased $15.7 \%$ in 2009, reaching 1,240,813 t, of which 39\% (132,000 t/year) are from tilapia culture (MPA, 2010).

To supply these growth indexes and the expansion of tilapia farming in Brazil, productive practices able to provide larger and high-quality offspring are necessary (Tsadik \& Bart, 2007). For that, improved nutrition, feeding and management of broodstock are essential tools (Bhujel et al., 2007), given that the nutrients used by females during vitellogenesis might impact both the quality and the chemical features of eggs (Tyler \& Sumpter, 1996; Wiegand, 1996; Izquierdo et al., 2001) and consequently the progeny development (Pereira et al., 2009).

In spite of the notorious influence of broodstock nutrition on breeding performance of males (Moraes et al., 2004), females (Ng \& Wang, 2011) and offspring (Gunasekera et al., 1996; Pereira et al., 2009; Sink et al., 2010), broodstock nutrition is a not well known segment of nutrition in bony fishes (Izquierdo et al., 2001). This lack of information about the specific broodstock nutritional requirements in fish (Bhujel et al., 2001; Lupatsch et al., 2010) has driven the recent development in research studies on both tilapia (El-Gamal et al., 2007; Sink \& Lochman, 2008; Sink et al., 2010; Ng \& Wang, 2011) and other commercial freshwater (Parra et al., 2008; Navarro et al., 2010) and marine (FernandezPalacios et al., 1995; Mazzorra et al., 2003) fish cultures.

Proteins and lipids stand out as the most important nutrients for mobilization and formation of body tissues (Cyrino et al., 2000). Moreover, both nutrients play a major role in reproduction (Çek \& Yilmaz, 2009), since they are the main components of yolk and have a direct influence on embryonic development (El-Sayed \& Kawanna, 2008). However, there are few studies about the effects of broodstock feeding or nutrition over progeny features in fish (Izquierdo et al., 2001).

The objective of this work was to evaluate the effects of Nile tilapia (Oreochromis niloticus) broodstock nutrition using diets with different levels of digestible protein and energy on their offspring performance. 


\section{Material and Methods}

The experimental period was from January 21 st to February 21st, 2011. The procedures were performed according to protocol $\# 07 / 2010$ and approved by the Ethics Committee of Experimentation and Practices with Animals from Unioeste (CEEAAP/Unioeste).

In this study were used 567 females $(161.4 \pm 33.7 \mathrm{~g}$; $16.9 \pm 1.5 \mathrm{~cm})$ and 189 males $(255.1 \pm 79.4 \mathrm{~g} ; 19.9 \pm 5.4 \mathrm{~cm})$ of Nile tilapia (Oreochromis niloticus) at 13 months of age. The breeding management of specimens was carried out from the 9th to the 13th months of age, employing 10 days for resting and four days for mating at a sex ratio of $1: 3$ (male:female). The broodstock was fed from the 2 nd to the 13th months of age with nine diets containing a combination of different levels of digestible protein $(28,34$ and $40 \%$ of DP) and digestible energy $(2,800 ; 3,400$; and 4,000 kcal of DE.kg of diet $^{-1}$ ) (Table 1).

The experimental diets offered to breeders were formulated at the Laboratory of Nutrition of Aquatic Organisms of UFPR. The feeds were ground in a hammer mill, filtered through a $0.5 \mathrm{~mm}$ sieve and pelletized (Meurer et al., 2003a) to $3 \mathrm{~mm}$ in diameter (Tessaro et al., 2012a).

When the breeders were at 13 months of age, 2,700 post-larvae were obtained from a single mating period. After the reproduction and production of offspring, 30 five-day-old post-larvae derived from the breeders fed the nine diets were collected in each treatment to measure initial values of weight $(\mathrm{mg})$, standard length $(\mathrm{cm})$ and total length $(\mathrm{cm})$. Afterwards, 1,890 post-larvae of same age were divided into 27 tanks $(70 \mathrm{~L}$ each) with a storage density of 1 fish. $\mathrm{L}^{-1}$. The tanks were equipped with a semiclosed water recirculation system, mechanical filters and automatic controlled temperature using electric heaters $\left(27 \pm 1{ }^{\circ} \mathrm{C}\right)$.

A statistical randomized bifactorial design (identical to that applied to breeders), composed of nine treatments and three repetitions was used. The offspring from the broodstock fed the nine diets containing the combination between the three levels of digestible protein $(28,34$ and $40 \%$ DP) and three levels of digestible energy $(2,800$; 3,400; and 4,000 kcal of DE.kg of diet $^{-1}$ ) were regarded as treatments (Table 1). Each $70 \mathrm{~L}$ tank containing 70 tilapia post-larvae was considered an experimental unit.

The post-larvae from each experimental unit were fed commercial bran diets (Meurer et al., 2003b), containing $42 \%$ of crude protein, 4,200 kcal of gross energy.kg of diet $^{-1}$ and $60 \mathrm{mg}$ of $17 \alpha$-methyltestosterone.kg of diet ${ }^{-1}$ (Kubitza, 2000). The post-larvae were fed ad libitum four times a day (8h30,10h30,14h30 and 17h30) (Sanches \& Hayashi, 2001).

Tanks were siphoned twice daily so as to remove feces and feed wastes. During this process, $20 \%$ of total water volume in the experimental units was changed (Meurer et al., 2002).

Table 1 - Percentage composition of ingredients and nutrients of experimental diets supplied to broodstock of Nile tilapia (Oreochromis niloticus)

\begin{tabular}{|c|c|c|c|c|c|c|c|c|c|}
\hline \multirow{4}{*}{ Parameters } & \multicolumn{9}{|c|}{ Digestible protein level (\%) } \\
\hline & \multicolumn{3}{|c|}{28} & \multicolumn{3}{|c|}{34} & \multicolumn{3}{|c|}{40} \\
\hline & \multicolumn{9}{|c|}{ Digestible energy level (kcal DE.kg of diet ${ }^{-1}$ ) } \\
\hline & 2800 & 3400 & 4000 & 2800 & 3400 & 4000 & 2800 & 3400 & 4000 \\
\hline Soybean meal & 52.92 & 44.06 & 46.27 & 68.57 & 62.55 & 63.37 & 83.99 & 58.25 & 26.06 \\
\hline Cornmeal & 30.31 & 32.86 & 19.52 & 13.90 & 15.94 & 3.00 & 0.00 & 5.00 & 1.00 \\
\hline Fish meal & 5.00 & 12.76 & 13.13 & 6.22 & 11.44 & 13.02 & 0.29 & 30.20 & 60.81 \\
\hline Inert material & 5.24 & 0.00 & 0.00 & 6.00 & 0.00 & 0.00 & 5.00 & 0.00 & 0.00 \\
\hline Wheat gluten & 0.00 & 0.00 & 0.00 & 0.00 & 0.00 & 0.00 & 4.38 & 0.00 & 0.00 \\
\hline $\operatorname{Premix}^{1}$ & 3.00 & 3.00 & 3.00 & 3.00 & 3.00 & 3.00 & 3.00 & 3.00 & 3.00 \\
\hline Dicalcium phosphate & 1.92 & 0.00 & 0.00 & 1.30 & 0.00 & 0.00 & 2.84 & 0.00 & 0.00 \\
\hline Soybean oil & 1.00 & 6.70 & 17.45 & 0.50 & 6.56 & 17.10 & 0.00 & 3.04 & 8.62 \\
\hline Common salt & 0.50 & 0.50 & 0.50 & 0.50 & 0.50 & 0.50 & 0.50 & 0.50 & 0.50 \\
\hline DL-methionine & 0.10 & 0.10 & 0.12 & 0.00 & 0.00 & 0.00 & 0.00 & 0.00 & 0.00 \\
\hline $\mathrm{BHT}^{2}$ & 0.01 & 0.01 & 0.01 & 0.01 & 0.01 & 0.01 & 0.01 & 0.01 & 0.01 \\
\hline \multicolumn{10}{|l|}{ Nutrients (\%) } \\
\hline Linoleic acid & 1.50 & 4.57 & 10.14 & 1.03 & 4.30 & 9.75 & 0.67 & 2.18 & 4.90 \\
\hline Starch & 26.02 & 26.42 & 18.41 & 17.91 & 18.37 & 10.42 & 11.94 & 10.98 & 4.14 \\
\hline Calcium & 1.10 & 1.28 & 1.32 & 1.09 & 1.22 & 1.36 & 1.0 & 2.86 & 5.46 \\
\hline Fat & 3.34 & 10.22 & 20.60 & 2.83 & 9.67 & 20.04 & 1.36 & 8.97 & 19.04 \\
\hline Total phosphorus & 1.0 & 1.0 & 1.0 & 1.0 & 1.0 & 1.0 & 1.06 & 1.92 & 3.30 \\
\hline Fiber & 2.71 & 2.64 & 2.01 & 2.21 & 2.18 & 1.54 & 1.88 & 1.53 & 0.62 \\
\hline
\end{tabular}


The water temperature was checked twice a day (7h00 and 14h00) prior to cleaning by using a thermometer with a precision of $\pm 1^{\circ} \mathrm{C}$. The dissolved oxygen (digital oximeter $\mathrm{YSI}^{\circledR}$ 550A) and $\mathrm{pH}$ (digital pHmeter Tecnal ${ }^{\circledR}$ Tec 5) of water were measured weekly at $07 \mathrm{~h} 00$, prior to cleaning.

At the end of the experimental period, all fish from experimental units were anesthetized and sacrificed by immersion in an aqueous solution with $250 \mathrm{mg}$ of benzocaine. $L^{-1}$ (CFMV, 2008). Then, the tilapias were weighed and the standard and total lengths were measured individually with a digital scale (MARTE ${ }^{\circledR}$ AS2000) with $\pm 0.01 \mathrm{~g}$ precision and an ichthyometer with $\pm 0.1 \mathrm{~cm}$ precision, respectively. Next, all fries were fixed in $10 \%$ formaldehyde (Bombardelli et al., 2007) and the effectiveness of sex reversal was analyzed by staining the gonads with acetocarmine and observation using an optical microscope, according to Pompa \& Green (1990).

Based on the obtained data, the average final weight (AFW, mg), average weight gain (AWG, mg), final standard length (SL, cm), condition factor (CF) (Vazzoler, 1996), specific growth rate (SGR \%/day) (Bomfim et al., 2005), stock uniformity (UNI, \%) (Oliveira, 2010), survival (SUR, \%) and sex reversal rate (SRR, \%) were calculated.

The results were analyzed using multiple regression based on generalized linear models, using a significance level of $5 \%$. These procedures were performed using the software Statistica $7.0^{\circledR}$.

\section{Results and Discussion}

The mean values verified for temperature, level of dissolved oxygen and water $\mathrm{pH}$ in the experimental tanks were $27.95 \pm 1.90{ }^{\circ} \mathrm{C} ; 6.83 \pm 1.18 \mathrm{mg} . \mathrm{L}^{-1}$ and $8.34 \pm 0.22$, respectively. These values are within the limits considered satisfactory for proper development of Nile tilapias in early stages (El-Sayed, 2006).
The present results indicate that feeding tilapia broodstock diets containing different amounts of digestible protein and digestible energy had no influence $(\mathrm{P}>0.05)$ on either growth or survival of offspring during the first 30 days of development (Table 2). In agreement with the present study, Gunasekera et al. (1996) did not observe difference for average body weight, total length and standard length of Nile tilapia larvae from females fed diets with 20 and $35 \% \mathrm{CP}$.

In spite of the inconsistency of the nutrition of breeders on progeny performance, the values observed for average final weight ( 0.31 to $0.38 \mathrm{~g}$ ), average weight gain ( 0.30 to $0.36 \mathrm{~g})$, standard length ( 2.04 to $2.24 \mathrm{~cm})$, condition factor (3.12 to 3.86$)$, specific growth rate (4.91 to $5.19 \%$ /day), stock uniformity ( 81.7 to 98.5 ), survival (97 to $100 \%$ ) and sex reversal rate $(100 \%)$ in Nile tilapia post-larvae can be regarded as zootechnically adequate for the end of the sex reversal stage (Toyama et al., 2000; Meurer et al., 2003b; Bombardelli \& Hayashi, 2005; Boscolo et al., 2005; Meurer et al., 2007; Oliveira, 2010) (Table 2).

Besides the reproductive performance, broodstock nutrition is also important for the quality of offspring. Some studies have reported the relevance of the balance between protein and energy in fish diets (Bomfim et al., 2005; Cotan et al., 2006; Piedras et al., 2006; Ali et al., 2008). If this ratio is unbalanced during fish growth, the proteins in the diet can be used as energy source (Kubitza, 2000) or directed to protein metabolism (Meurer et al., 2002). On the other hand, in the case of broodstock, this balance can be directly related to breeding performance (Lupatsch et al., 2005) or physiology processes such as vitellogenesis (Bromage, 1995).

A previous report about feeding Nile tilapia females diets with 10 to $40 \%$ of protein showed that protein levels could influence the gonadal maturation but not the chemical composition of eggs (Gunasekera et al., 1995). A

Table 2 - Performance parameters of Nile tilapia (Oreochromis niloticus) offspring derived from breeders fed diets containing different levels of digestible protein and digestible energy during sex reversal phase

\begin{tabular}{|c|c|c|c|c|c|c|c|c|c|c|}
\hline \multirow{4}{*}{ Parameters } & \multicolumn{9}{|c|}{ Digestible protein level (\%) } & \multirow{4}{*}{ P-value } \\
\hline & \multicolumn{3}{|c|}{28} & \multicolumn{3}{|c|}{34} & \multicolumn{3}{|c|}{40} & \\
\hline & \multicolumn{9}{|c|}{ Digestible energy level (kcal DE.kg of diet $^{-1}$ ) } & \\
\hline & 2800 & 3400 & 4000 & 2800 & 3400 & 4000 & 2800 & 3400 & 4000 & \\
\hline Average final weight (g) & 0.33 & 0.35 & 0.34 & 0.38 & 0.33 & 0.32 & 0.31 & 0.35 & 0.35 & 0.37 \\
\hline Average weight gain (g) & 0.33 & 0.35 & 0.33 & 0.37 & 0.32 & 0.31 & 0.30 & 0.34 & 0.34 & 0.36 \\
\hline SL & 2.13 & 2.17 & 2.09 & 2.20 & 2.21 & 2.09 & 2.08 & 2.15 & 2.16 & 0.36 \\
\hline Condition factor & 3.48 & 3.46 & 3.74 & 3.57 & 3.13 & 3.54 & 3.47 & 3.52 & 3.50 & 0.65 \\
\hline SGR (\%/day) & 5.17 & 5.06 & 5.17 & 5.20 & 5.04 & 4.94 & 4.84 & 5.06 & 5.10 & 0.16 \\
\hline Stock uniformity (\%) & 90.0 & 94.8 & 85.2 & 86.6 & 95.7 & 89.5 & 93.9 & 88.8 & 85.2 & 0.70 \\
\hline Survival (\%) & 94.3 & 99.0 & 91.9 & 97.1 & 98.1 & 98.6 & 100 & 98.6 & 94.8 & 0.60 \\
\hline Sex reversal rate $(\%)$ & 100 & 100 & 100 & 100 & 100 & 100 & 100 & 100 & 100 & - \\
\hline
\end{tabular}

SL - average standard length; SGR - specific growth rate. 
similar effect was also recently reported by Lupatsch et al. (2010), when different feeding managements in females of Nile tilapia were tested, with a diet with $23.5 \mathrm{~g}$ of digestible protein.MJ of digestible energy ${ }^{-1}$.

According to Gunasekera et al. (1996), high levels of protein affect the viability of offspring up to the sixth day of development. Apart from protein, other nutritional components might also interfere with the quality of progeny. The increase in the levels of digestible energy in the diet of tilapia broodstock may improve the post-larvae vigor. Such influence of broodstock nutrition on offspring performance seems to be caused by physiological processes (Navas et al., 1998) related to both production and incorporation of vitellogenin in oocytes (Coward et al., 2002). The yolk is the main nutritional source of fries during their first days of development because it makes elements important for molecule formation available (Vassalo-Agius et al., 2001) or acts as an energetic component (Tyler \& Sumpter, 1996).

Although the yolk sac ensures the endogenous nutritional storage during the initial life stages (Mazorra et al., 2003), little is known about the influence of maternal nutrition on growth of post-larvae when they no longer depend on their endogenous reserves. Ng \& Wang (2011) verified that the utilization of crude palm oil in the diet of tilapia broodstock influenced the gonadal development, egg production, hatchability and larval normality. However, the offspring development up to total yolk consumption was unaffected by the oil source.

Studies on fish broodstock nutrition focusing on longer periods of offspring development, in either fries or juveniles, are even more restricted. Sink \& Lochman (2008) fed breeders of Ictalurus punctatus diets containing 4 and $10 \%$ of lipids and raised the offspring up to 37 days of age, observing no effects on their growth.

The period of experimental feeding of the broodstock might also influence their reproductive and offspring performance. This period possibly had no effects on present results, since breeders were fed for 11 months and most research studies recommend experimental periods of, at least, 165 (El-Sayed et al., 2005) or 175 days ( $\mathrm{Ng} \mathrm{\&}$ Wang, 2011) to observe dietary effects on tilapia breeding. Therefore, broodstock diet seems to interfere on offspring performance only during the periods of endogenous feeding of larvae, particularly related to yolk composition.

Another aspect to be remarked concerns the high fat content in diets formulated with the highest levels of digestible energy. Regardless of its effects on offspring, these diets might cause medium-term or long-term physiological damages to the broodstock since they promote liver fat deposition and steatosis (Tessaro et al., 2012b).
Thus, furthers studies related to overall dietary effects on both fish breeding performance and reproductive life are recommended.

Evidence suggests that female nutrition might influence the reproductive performance or offspring quality in different manners. Although this management can affect the viability of offspring during early stages, the results of this study indicate that there is no influence of broodstock nutrition on growth or survival of progeny during periods when they no longer depend on endogenous reserves as feed or nutritional sources.

\section{Conclusions}

Feeding diets containing different levels of digestible protein and digestible energy to tilapia broodstock according to the experimental design adopted has no effects on growth or quality of offspring during 30 days of development.

\section{References}

ALI, B.A.; AL-OGAILY, S.M.; AL-ASGAH, N.A. et al. Effect of feeding different protein to energy $(\mathrm{P} / \mathrm{E})$ ratios on the growth performance and body composition of Oreochromis niloticus fingerlings. Journal of Applied Ichthyology, v.24, p.31-37, 2008.

BHUJEL R.C.; YAKUPITIYAGE, A.; TURNER, A.W. et al. Selection of a commercial feed for Nile tilapia (Oreochromis niloticus) broodfish breeding in a hapa-in-pond system. Aquaculture, v.194, p.303-314, 2001.

BHUJEL, R.C.; LITTLE, D.C.; HOSSAIN, A. Reproductive performance and the growth of pre-stunted and normal Nile tilapia (Oreochromis niloticus) broodfish at varying feeding rates. Aquaculture, v.273, p.71-79, 2007.

BOMBARDELLI, R.A.; HAYASHI, C. Masculinização de larvas de Tilápia do Nilo (Oreochromis niloticus L.) a partir de banhos de imersão com 17a-metiltestosterona. Revista Brasileira de Zootecnia, v.34, p.365-372, 2005.

BOMBARDELLI, R.A.; SANCHES, E.A.; PINTO, D.F.H. et al. Idade de maior sensibilidade de tilapias-do-Nilo aos tratamentos de masculinização por banhos de imersão. Revista Brasileira de Zootecnia, v.36, p.1-6, 2007.

BOMFIM, M.A.D.; LANNA, E.A.T.; SERAFINI, M.A. et al. Proteína bruta e energia digestível em dietas para alevinos de Curimbatá (Prochilodus affinis). Revista Brasileira de Zootecnia, v.34, p.1795-1806, 2005.

BOSCOLO, W.R.; HAYASHI, C.; MEURER, F. et al. Farinha de resíduos da filetagem de tilápias na alimentação de Tilápia-doNilo (Oreochromis niloticus) na fase de reversão sexual. Revista Brasileira de Zootecnia, v.34, p.1807-1812, 2005.

BROMAGE, N. Broodstcok management and seed quality - general considerations. In: BROMAGE, N.R.; ROBERTS, R.J. (Eds.) Broodstock management and egg and larval quality. London: Blackwell Science Ltd, 1995. p.1-25.

ÇEK, S.; YILMAZ, E. The effect of varying dietary energy on gonad development at first sexual maturity of the Sharptooth catfish (Clarias gariepinus Burchell, 1822). Aquaculture Internacional, v.17, p.553-563, 2009.

CONSELHO FEDERAL DE MEDICINA VETERINÁRIA - CFMV. Resolução no 876, de 15-02-2008, publicada no DOU de 25-02-2008. Seção 1, p.100. 
COTAN, J.L.V.; LANNA, E.A.T.; BOMFIM, M.A.D. et al. Níveis de energia digestível e proteína bruta em rações para alevinos de lambari tambiú. Revista Brasileira de Zootecnia, v.35, p.634-640, 2006.

COWARD, K.; BROMAGE, N.R.; HIBBITT, O. et al. Gamete physiology, fertilization and egg activation in teleost fish. Reviews in Fish Biology and Fisheries, v.12, p.33-58, 2002.

CYRINO, J.E.P.; PORTZ, L.; MARTINO, R.C. Retenção de proteína e energia em juvenis de "black bass" Micropterus salmoides. Scientia Agricola, v.57, p.609-616, 2000.

EL-GAMAL, A.H.E.; EL-GREISY, Z.A.; EL-EBIARY, E.H. Synergistic effects of vitamins $\mathrm{C}$ and $\mathrm{E}$ and selenium on the reproductive performance of Nile Tilapia, Oreochromis niloticus. Journal of Applied Sciences Research, v.3, p.564-573, 2007.

EL-SAYED, A.F.M. Tilapia culture. Alexandria, Egypt: Oceanography Department, Faculty of Science, Alexandria University, 2006. 277p.

EL-SAYED, A.M.; MANSOUR, C.R.; EZZAT, A.A. Effects of dietary lipid source on spawning performance of Nile tilapia (Oreochromis niloticus) broodstock reared at different water salinities. Aquaculture, v.248, p.187196, 2005.

EL-SAYED, A.M.; KAWANA, M. Effects of dietary protein and energy levels on spawning performance of Nile tilapia (Oreochromis niloticus) broodstock in a recycling system. Aquaculture, v.280, p.179-184, 2008

FERNANDEZ-PALACIOS, H.; IZQUIERDO, M.S.; ROBAINA, L. et al. Effect of n-3 HUFA level in broodstock diets on egg quality of gilthead sea bream (Sparus aurata L.). Aquaculture, v.132, p.325-337,1995.

FOOD AND AGRICULTURE ORGANIZATION OF THE UNITED NATIONS - FAO. El estado mundial de la pesca y la acuicultura. Roma: Subdivisión de Políticas y Apoyo en Materia de Publicación Electrónica. Rome, 2010. 193p.

GUNASEKERA, R.M.; SHIM, K.F.; LAM, T.J. Effects of dietary protein level on puberty, oocyte growth and egg chemical composition in the tilapia, Oreochromis niloticus (L.). Aquaculture, v.134, p.169-183, 1995.

GUNASEKERA, R.M.; SHIM, K.F.; LAM, T.J. Influence of protein content of broodstock diets on larval quality and performance in Nile tilapia, Oreochromis niloticus (L.). Aquaculture, v.146, p.245-259, 1996.

IZQUIERDO, M.S.; FERNANDEZ-PALACIOS, H.; TACON, A.G.J. Effect of broodstock nutrition on reproductive performance of fish. Aquaculture, v.197, p.25-42, 2001.

KUBITZA, F. Tilápia - tecnologia e planejamento na produção comercial. 1.ed. Jundiaí: Divisão de Biblioteca e Documentação, 2000. 289p.

LUPATSCH, I.; KISSIL, G.W. Feed formulations based on energy and protein demands in white grouper (Epinephelus aeneus). Aquaculture, v.248, p.83-95, 2005.

LUPATSCH, I.; DESHEV, R.; MAGEN, I. Energy and protein demands for optimal egg production including maintenance requirements of female tilapia (Oreochromis niloticus). Aquaculture Research, v.41, p.763-769, 2010.

MAZORRA, C.; BRUCE, M.; BELL, J.G. Dietary lipid enhancement of broodstock reproductive performance and egg and larval quality in Atlantic halibut (Hippoglossus hipoglossus). Aquaculture, v.227, p.21-33, 2003.

MEURER, F.; HAYASHI, C.; BOSCOLO, W.R. et al. Lipídeos na alimentação de alevinos revertidos de Tilápia do Nilo (Oreochromis niloticus, L.). Revista Brasileira de Zootecnia, v.31, p.566-573, 2002.

MEURER, F.; HAYASHI, C.; BOSCOLO, W.B. Digestibilidade Aparente de Alguns Alimentos Protéicos pela Tilápia do Nilo (Oreochromis niloticus). Revista Brasileira de Zootecnia, v.32, p.1801-1809, 2003a.

MEURER, F.; HAYASHI, C.; BOSCOLO, W.B. Influência do processamento da ração no desempenho e sobrevivência da Tilápia do Nilo durante a reversão sexual. Revista Brasileira de Zootecnia, v.32, p.262-267, 2003b.
MEURER, F.; HAYASHI, C.; BOSCOLO, W.R. et al. Exigência de proteína digestível para juvenis de tilápia do Nilo em baixa temperatura. Revista Científica de Produção Animal, v.9, p.53-64, 2007.

MINISTÉRIO DA PESCA E AQUICULTURA - MPA. [2010]. Produção de pescado aumenta $25 \%$. Available at: $<\mathrm{http} / /$ : www.mpa.gov.br/\#imprensa/2010/AGOSTO/nt_AGO_19-08Producao-de-Pescado-aumenta $>$. Accessed on: Sept. 25, 2011.

MORAES, G.V.; STREIT JR., D.P.; RIBEIRO, R.P. et al. Ação de diferentes indutores reprodutivos hormonais no aparecimento de anormalidades morfológicas em espermatozóides de piavuçu (Leporinus macrocephalus), curimbatá (Prochilodus lineatus) e carpa comum (Cyprinus carpio). Boletim do Instituto de Pesca, v.32, p.109-116, 2004.

NAVARRO, R.D.; MALDONADO, I.R.S.C.; MATTA, S.L.P. et.al. Associação do nível de energia digestível no comprimento total, peso das gônadas e índice gonadossomático de fêmeas de Piauçu ("Leporinus macrocephalus", SPIX 1829) em estágio pós-larval. Revista Brasileira de Saúde e Produção Animal, v.11, p.242-251, 2010.

NAVAS, J.M.; MANÃNOS, E.; THRUSH, M. et al. Effect of dietary lipid composition on vitellogenin,17b-estradiol and gonadotropin plasma levels and spawning performance in captive sea bass (Dicentrarchus labrax L.). Aquaculture, v.165, p.65-79, 1998.

NG, W.; WANG, Y. Inclusion of crude palm oil in the broodstock diets of female Nile tilapia, Oreochromis niloticus, resulted in enhanced reproductive performance compared to broodfish fed diets with added fish oil or linseed oil. Aquaculture, v.314, p.122-131, 2011.

OLIVEIRA, L.C. Altas frequências de arraçoamento nas fases iniciais da criação de tilápia em hapas. 2010. 74f. Tese (Doutorado em Zootecnia) - Universidade Estadual Paulista, Botucatu.

PARRA, J.E.G.; RADÜNZ NETO, J.; VEIVERBERG, C.A. et al. Alimentação de fêmeas de jundiá com fontes lipídicas e sua relação com o desenvolvimento embrionário e larval. Ciência Rural, v.38, p.2011-2017, 2008.

PEREIRA, T.S.; FABREGAT, T.H.P.; FERNANDES, J.B.K. et al. Selênio orgânico na alimentação de matrizes de tilápia-do-Nilo (Oreochromis niloticus). Acta Scientiarum, v.31, p.433-437, 2009.

PIEDRAS，S.R.N.; POUEY，J.L.O.F.; MORAES，P.R.R. et al. Resposta de alevinos de jundiá (Rhamdia $s p$.) alimentados com diferentes níveis de proteína bruta e energia digestível. Revista Brasileira de Agrociência, v.12, p.217-220, 2006.

POPMA, T.J.; GREEN, B.W. Aquacultural production manual: sex reversal of tilapia in earthen ponds. Research and Development Series, v.35, p.1-15, 1990.

SANCHES, L.E.F.; HAYASHI, C. Effect of feeding frequency on Nile tilapia, Oreochromis niloticus (L.) fries performance during sex reversal in hapas. Acta Scientiarum Animal Science, v.23, p.871-876, 2001.

SINK, T.D.; LOCHMAN, R.T. Effects of dietary lipid source and concentration on channel catfish (Ictalurus punctatus) egg biochemical composition, egg and fry production, and egg and fry quality. Aquaculture, v.283, p.68-76, 2008.

SINK, T.D.; LOCHMAN, R.T.; POHLENZ, C. et al. Effects of dietary protein source and protein-lipid source interaction on channel catfish (Ictalurus punctatus) egg biochemical composition, egg production and quality, and fry hatching percentage and performance. Aquaculture, v.298, p.251-259, 2010.

TESSARO, L.; TOLEDO, C.P.R.; NEUMANN, G. et al. Growth and reproductive characteristics of Rhamdia quelen males fed on different digestible energy levels in the reproductive phase. Aquaculture, v.326-329, p.74-80, 2012a.

TESSARO, L.; TOLEDO, C.P.R.; NEUMANN, G. et al. Animal performance and reproductive aspects of female Rhamdia quelen fed on different levels of digestible energy. Aquaculture Research, v.1, p.1-9, 2012b. 
TOYAMA, G.N; CORRENTE, J.E.; CYRINO, J.E.P. Suplementação de vitamina $\mathrm{c}$ em rações para reversão sexual da tilápia do Nilo. Scientia Agricola, v.57, p.221-228, 2000.

TSADIK, G.G.; BART, A.N. Effects of feeding, stocking density and water-flow rate on fecundity, spawning frequency and egg quality of Nile tilapia, Oreochromis niloticus (L.). Aquaculture, v.272, p.380-388, 2007.

TYLER, C.R.; SUMPTER, J.P. Oocyte growth and development in teleosts. Reviews in Fish Biology and Fisheries, v.6, p.287-318, 1996.
VASSALO-AGIUS, R.; WATANABE, T.; YOSHIZAKI, G. et al. Quality of eggs and spermatozoa of Rainbow trout fed an n-3 essential fatty acid-deficient diet and its effects on the lipid and fatty acid components of eggs, semen and livers. Fisheries Science, v.67, p.818-827, 2001.

VAZZOLER, A.E.A.M. Biologia da reprodução de peixes teleósteos: teoria e prática. 1.ed. Maringá: EDUEM, 1996. 169p.

WIEGAND, M.D. Composition, accumulation and utilization of yolk lipids in teleost fish. Reviews in Fish Biology and Fisheries, v.6, p.259-286, 1996. 